\title{
Sistim Monitoring Pada Sorting Machine dengan HMI Berbasis PLC
}

\author{
Doli Hasbi Simanjuntak ${ }^{1}$, Risfendra ${ }^{2}$ \\ 1,2 Universitas Negeri Padang \\ Jl. Prof Dr. Hamka Air Tawar, Padang, Indonesia \\ dolihasbisimanjuntak@gmail.com ${ }^{1}$,risfendra@ft.unp.ac.id ${ }^{2}$
}

\begin{abstract}
In today's big industry, the use of PLCs is usually paired with an interface device, namely HMI. The application of the results of the development of the object sorting tool in the Department of Electrical Engineering, Faculty of Engineering, State University of Padang is still facing several obstacles, one of which is that the manufacture of tools is still controlled by the PLC. Improvements are needed to the object sorting tool by adding a monitoring system. This is done in an effort to improve the quality of control by using PLC as a control system and the performance of the HMI WEINTEK 8071ip can help to control and monitor the work system of the tool. In designing Omron brand PLC communication with the WEINTEK 8071iP HMI begins with making block diagrams and system flowcharts. The object sorting system controlled by the OMRON type CP1E PLC will be displayed on the WEINTEK 8071iP HMI using EasyBuilderPro software. This tool is expected to improve performance as a control and monitoring tool. The HMI control system design for object sorting tools using the HMI WEINTEK MT8071iP runs according to its function as a control medium and system monitoring.
\end{abstract}

Keywords: Control System, Object Sorting Tool, HMI WEINTEK MT8071Ip,PLC Omron CP1E.

Abstrak - Di industri besar saat sekarang ini penggunaan PLC biasanya dipasangankan dengan sebuah alat interface yaitu HMI. Penerapan hasil pengembangan alat sortir benda di Jurusan Teknik Elektro Fakultas Teknik Universitas Negeri Padang masih menemui beberapa kendala, salah satunya dikarenakan pembuatan alat masih dikontrol oleh PLC saja. Diperlukan penyempurnaan pada alat sortir benda dengan menambahkan sistem monitoring. Hal ini dilakukan dalam upaya peningkatan kualitas dalam penguasaan dengan menggunakan PLC sebagai sistem kontrol dan kinerja HMI WEINTEK 8071ip dapat membantu untuk mengontrol dan memonitoring sistem kerja alat. Dalam perancangan komunikasi PLC merk omron dengan HMI WEINTEK 8071iP diawali dengan pembuatan blok diagram dan flowchart sistem. Sistem alat sortir benda yang dikontrol dengan PLC merk OMRON type CP1E akan ditampilkan pada HMI WEINTEK 8071iP menggunakan software EasyBuilderPro. Alat ini diharapkan dapat meningkatkan kinerja sebagai kontrol dan monitoring alat. Perancangan sitem kontrol HMI untuk alat sortir benda menggunakan HMI WEINTEK MT8071iP berjalan sesuai dengan fungsinya sebagai media kontrol dan monitoring sistem.

Kata kunci: Sistem Kontrol, Alat Sortir Benda, HMI WEINTEK MT8071Ip,PLC Omron CP1E.

\section{PENDAHULUAN}

Meningkatnya hasil produksi mengakibatkan stok hasil produksi melimpah, sehingga dibutuhkan suatu sistem yang dapat menyimpan barang secara otomatis dengan tenaga mesin yang modern. Teknologi PLC (Progammable Logic Controller) muncul sebagai solusi untuk otomatisasi sistem tersebut. Pengguanaan PLC dimulai sejak tahun 1970-an dan menjadi pilihan utama dalam pengontrolan di industri manufaktur [1]. PLC merupakan suatu piranti yang memiliki saluran masukan dan saluran keluaran. Status masukan dan program yang dimasukkan kedalam PLC menentukan keluaran yang dihasilkannya. Mesin produksi diindustri telah menerapkan teknologi untuk menoptimalkan kinerja dan mengurangi kesalahan yang disebabkan oleh manusia. Dengan menerapkan tegnologi otomasi proses produksi dapat dilakukan secara tepat, dan bisa beroperasi 24 jam [2]

Di industri besar saat sekarang ini penggunaan PLC biasanya dipasangankan dengan sebuah alat interface yaitu HMI (Human Machine Interface). HMI yaitu sistem yang penghubung antara manusia dan mesin [3]. HMI juga berupa pengontrol yang memvisualisasikan status baik dengan manual maupun melalui visualisasi komputer yang bersifat nyata. Tugas dari HMI yaitu membuat visualisasi dari teknologi atau sistem secara nyata. Dengan desain pada HMI bisa disesuaikan sehingga mempermudah pekerjaan pada kadaan nyata. Tujuan dari HMI ini untuk mengoptimalkan komunikasi antara mesin dan pengguna melalui tampilan monitouch dan melengkapi kebutuhan pengguna untuk data informasi sistem [4].

Sistem otomasi adalah sistem yang bekerja menggabungkan sistem mekanik, elektrik, hidrolik dan pneumatik. Lazimnya untuk sistem otomasi menggunakan PLC yang terhubung dengan HMI sebagai media pengendali dan pemantauan untuk menggerakkan mesin-mesin sistem pneumatik dan lainnya[5].

Bagian antarmuka pada PLC belakangan ini sangat memiliki kekurangan. Namun, saat ini berkembang software- software yang mampu menampilkan antarmuka yang menarik bagi PLC. Software tersebut digunakan pada HMI Weintek yaitu dengan software EasyBuilderPro [6]. 
Pada pengembangan trainer elektropneumatik pada mata kuliah Praktikum Sistem Pengaturan (PLC dan Pneumatik) yang valid dan praktis di Jurusan Teknik Elektro Fakultas Teknik Universitas Negeri Padang, mahasiswa masih awam dalam menggunakan Pneumatik. Maka dari itu perlu adanya penyempurnaan pada trainer elektropneumatik yang akan digunakan pada mata kuliah Praktikum Sistem Pengaturan PLC dan Pneumatik [7].

Dari alat yang sudah dibuat sebelumnya oleh Firman (2018), pembuatan alat masih dikontrol oleh PLC saja [7]. Diperlukan adanya peningkatan sistem pada alat yaitu dengan melengkapi dengan sistem monitoring.

Pada rancangan yang akan dibuat ini, penulis berupaya meningkatkan kemampuan alat dengan menambahkan sistem monitoring menggunakan HMI WEINTEK sebagai alat pengontrolan dan monitoring yang sekarang mulai banyak digunakan pada industriindustri. Pada bidang Otomasi masih sedikit kajiankajian mendalam mengenai PLC, maka dengan adanya studi ini diharapkan adanya peningkatan kualitas dalam penguasaan dengan menggunakan PLC sebagai sistem kontrol dan kinerja HMI WEINTEK sebagai software HMI.

Pengontrolan trainer elektropneumatik menggunakan PLC dengan menggunakan HMI dapat memudahkan memantau keadaan pada trainer PLC elektropneumatik tanpa melihat secara langsung trainer ini bekerja. Dengan adanya pengembangan ini diharapkan adanya peningkatan dari bidang otomasi dan terciptanya banyak praktisi yang menguasai penggunaan PLC dan HMI.

Berdasarkan keterangan yang dijelaskan diatas. Kemudian, penulis mengangkat penulisan tentang sistem monitoring pada alat sorting machine dengan HMI berbasis PLC. Maka akan dibuat sebuah program yang menampilkan plant pada alat sortir benda yang pengendaliannya berbasis PLC jenis OMRON merk CP1E dengan menggunakan kabel USB (Universal Serial Bus) sebagai media komunikasi antara PC dengan HMI WEINTEK MT8071iP dan PC dengan PLC Omron type CP1E. Kabel Ethernet digunakan sebagai media komunikasi antara PC dengan HMI WEINTEK MT8071iP. Program dibuat dengan menampilkan bentuk plant antar muka alat sortir benda sedangkan untuk sistem yang dibuat merupakan software antarmuka pada HMI WEINTEK yang mampu memonitor maupun mengontrol kerja dari input dan output pada alat sortir benda.

\section{METODE}

Dalam perancangan komunikasi PLC Omron tipe CP1E dengan HMI WEINTEK MT8071iP akan dijelaskan tentang blok diagram dan flowchart.

\section{Blok Diagram}

Blok diagram adalah suatu pernyataan gambar yang ringkas, dari gabungan sebab dan akibat antara masukkan dan keluaran dari suatu sistem. Sistem kontrol terdiri dari sejumlah komponen yang terhubung untuk melakukan fungsi yang di inginkan. Blok diagram yang akan dibuat dapat dilihat pada Gambar 1 .

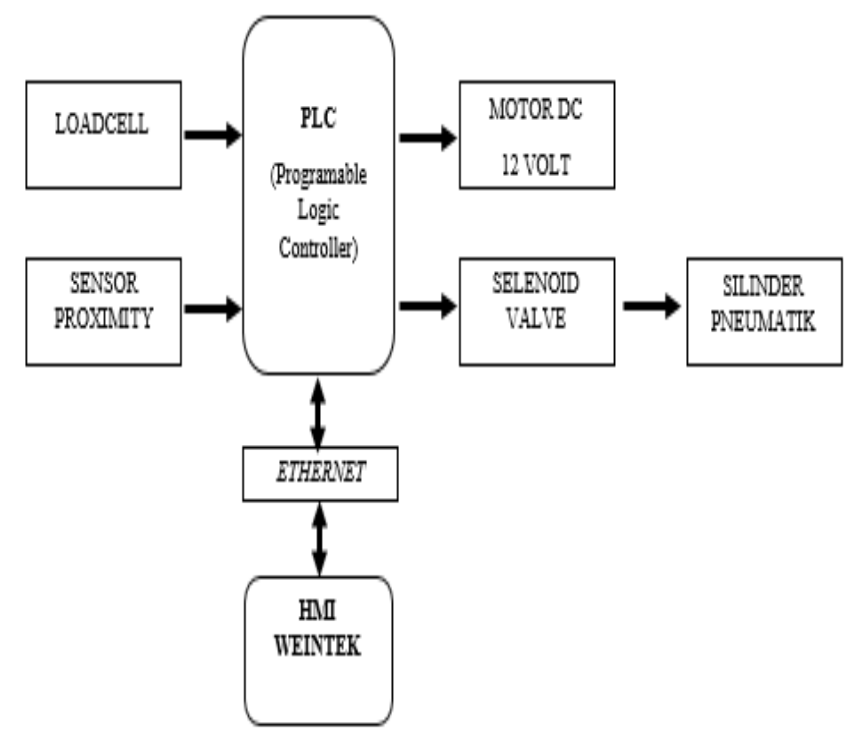

Gambar 1. Blok Diagram Perancangan rangkaian keseluruhan

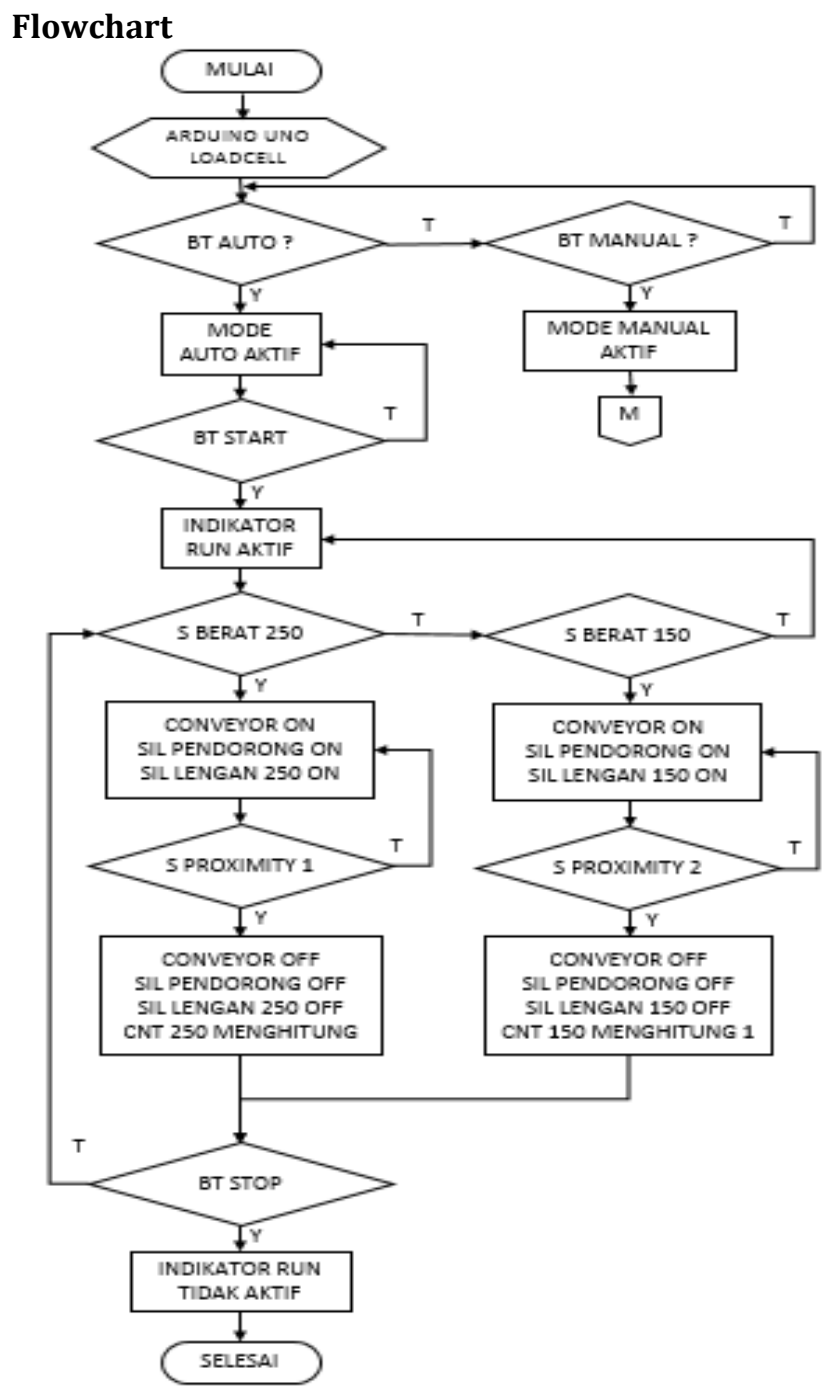

Gambar 2. Flowchart sistem Otomatis 


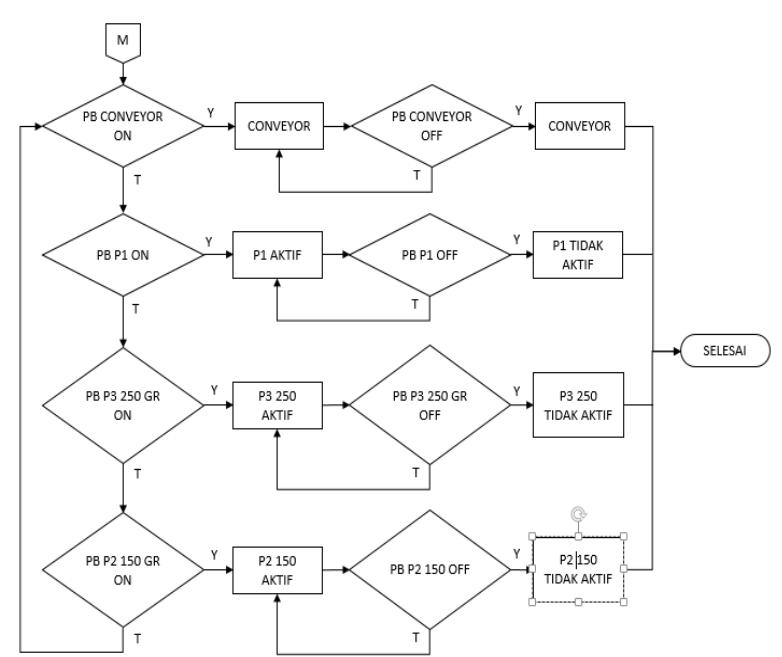

Gambar 3. Flowchart Sistem Manual

Pada Gambar 2 saat tombol start diaktifkan, alat melakukan proses inisialisasi dan Arduino Uno akan mengkalibrasikan sensor loadcell. Kemudian pilih mode pengontrolan auto atau manual pada halaman utama. Apabila mode auto (PB AUTO) dipilih maka Silinder pendorong (P1) akan aktif untuk mendorong benda ke Sensor Berat (Loadcell) Selanjutnya sensor berat (Loadcell) akan menimbang berat benda yang terbaca 150 gr atau 250 gr. Kemudian hasil penimbangan dari sensor berat akan diteruskan menjadi input ke PLC. Nilai dari sensor berat (Loadcell) yang diubah menjadi input digital ke PLC dan akan mengaktifkan kembali Silinder Pendorong (P1) kemudan konveyor (C) aktif bersamaan dengan aktifnya silinder lengan 150 gr (P2 150GR) atau Silinder 250 gr (P3 250GR). Benda yang telah terpisahkan oleh silinder lengan akan dideteksi oleh sensor proximity ketika benda melewati sensor tersebut dan silinder lengan p2 atau P3 akan non aktif. Program akan berhenti ketika tidak ada lagi benda yang terbaca oleh sensor berat/ loadcell atau menekan stop (PBSTOP) program.

Gambar 3 merupakan yang mode manual digunakan apabila perintah dilakukan untuk menjalankan output yang ada pada alat dengan menekan tombol Command button terhadap nama-nama output tersebut.

\section{PENGUJIAN DAN ANALISA DATA}

Pada bagian ini dijelaskan mengenai realisasi sistem, pengujian terhadap alat yang sudah dikerjakan, dan analisa sistem yang sudah direalisasikan. Realisasi meliputi pemograman perangkat lunak PLC dan HMI WEINTEK MT8071iP.

\section{Analisa Hasil Pengujian dalam Urutan Proses}

Urutan proses kerja sistem kontrol alat sortir benda menggunakan HMI WEINTEK MT8071iP mengikuti alur pada flowchart. Berikut ini urutan proses kerja alat:

1. Tampilan awal HMI dari alat sortir benda ini dapat dilihat pada Gambar 4 Untuk menjalankan sistem operator harus menekan tombol MANUAL atau tombol OTOMATIS pada tampilan virtual tersebut. Setelah menekan salah satu tombol tersebut maka akan dimulai inisialisasi.

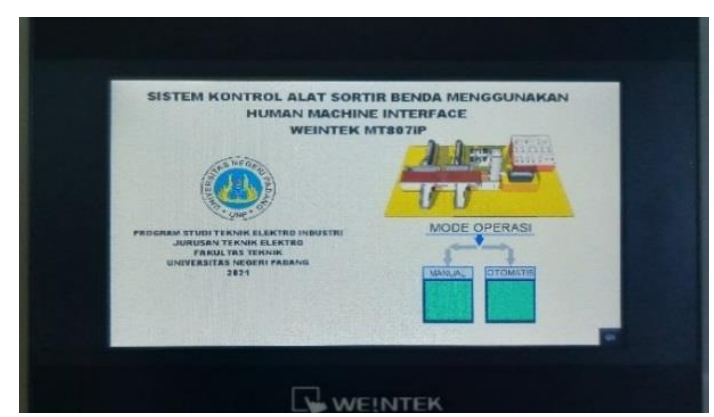

Gambar 4. Tampilan Halaman Utama pada HMI

2. Disaat tombol start manual ditekan maka tombol otomatis tidak dapat digunakan. Pada keadaan sebaliknya akan terjadi hal tersebut. Tombol stop digunakan untuk mengembalikan pada keadaan normal. Seperti yang dijelaskan pada pemrograman hanya salah satu mode yang akan aktif. Kedua mode akan non-aktif jika tombol stop ditekan yang dapat dilihat pada Gambar 5 yang merupakan ladder interlocking untuk mode otomats dan manual

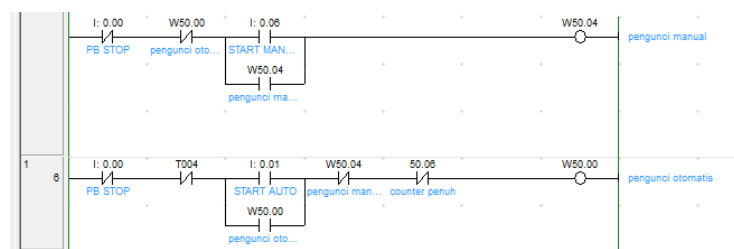

Gambar 5. Rangkaian interlocking otomastis dan manual

3. Jika mode yang dipilih adalah otomatis maka akan terlihat bagaimana proses sortir benda secara otomatis ditandai dengan lampu indikator RUN aktif, pneumatik 2- untuk keadaan normal aktif dan Pneumatik 3- untuk kadaan normal aktif. sistem akan berhenti secara otomatis ketika loadcell tidak bekerja selama 30 detik atau dengan menekan tombol stop. Gambar 6 memperlihatkan tampilan lampu menu otomatis ketika tombol start di tekan.

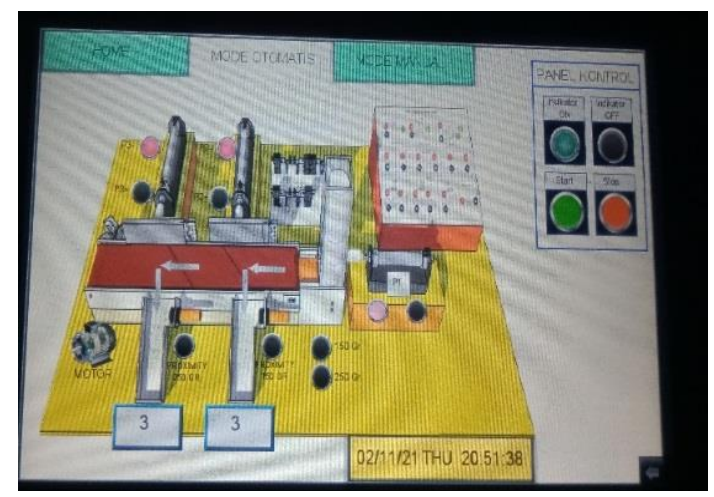

Gambar 6. Tampilan Indikator Sistem Pada Mode Otomatis 
4. Selanjutnya akan terjadi proses kalibrasi pada loadcell. Kemudian tanda lampu indikator masingmasing lampu pada HMI akan aktif untuk menginformasikan output yang akan bekerja. Jika lampu indikator menyala maka itu menandakan output mana yang sedang bekerja. Sistem akan berhenti secara otomatis apabila tidak ada benda yang terdeteksi dalam jangka waktu 40 detik. Gambar 7 adalah kondisi benda 150 gram ketika terdapat benda.

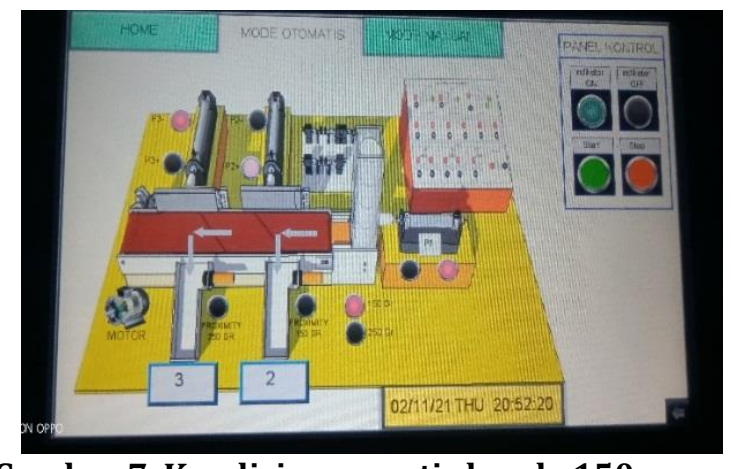

Gambar 7. Kondisi menyortir benda 150 gram

5. Kemudian ketika kondisi alat pada HMI mendeteksi benda 250 gram pada loadcell maka lampu pneumatik 3+ aktif yang dapat dilihat pada Gambar 8.

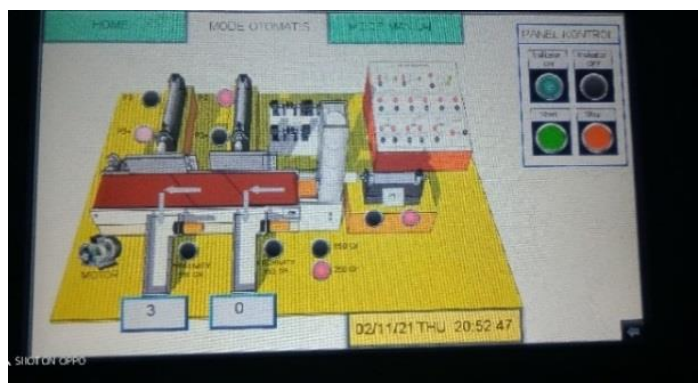

Gambar 8. Kondisi HMI mendeteksi benda 250 gram

6. Pada tampilan HMI benda yang terdeteksi akan ditandai dengan lampu indikator 250 gram atau 150 gram yang menyala. Kemudian benda benda tersebut akan di hitung dan ditampilkan pada HMI seperti Gambar 9. Sistem akan berhenti ketika benda 150 gram berjumlah 3 dan benda 250 gram berjumlah 3 .

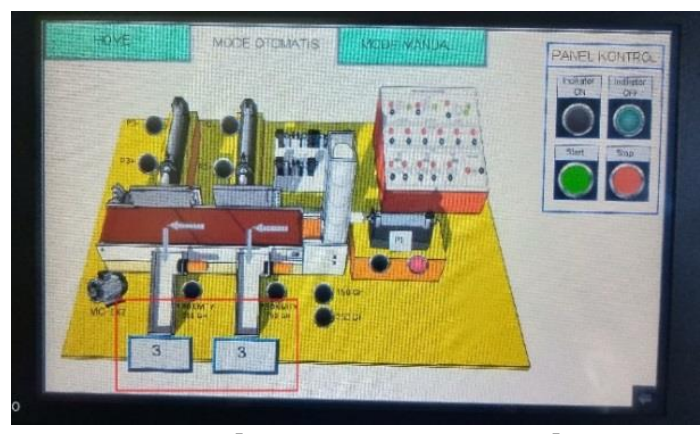

Gambar 9. Counter Penuh
7. Selanjutnya pada mode Manual Ketika tombol Start Manual dotekan maka sistem kerja pada mode otomatis tidak bisa bekerja. Pada Gambar 10 merupakan kondisi mode manual pada saat tombol virtual starat ditekan.

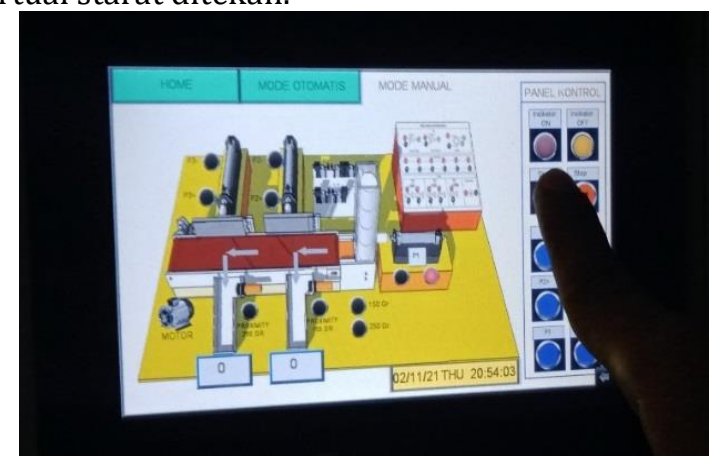

Gambar 10. Kondisi tombol start manual ditekan

8. Pada saat start mode manual telah aktif maka tombol tombol pada mode tersebut telah dapat diaktifkan seperti pada Gambar 11.

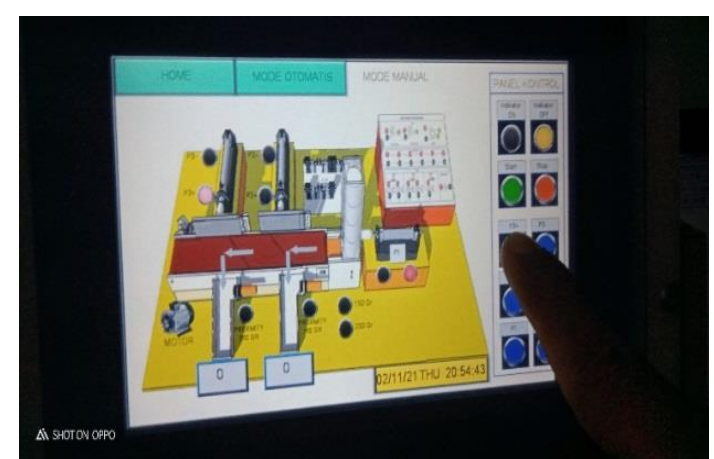

Gambar 11. Kondisi tombol virtual Pneumatik 3+ ditekan

Gambar 11 memperlihatkan kondisi ketika tombol Virtual pada HMI P3+ untuk Pneumatik 3 mendorong kedepan mengarahkan benda dijalur sortir 250 gram.

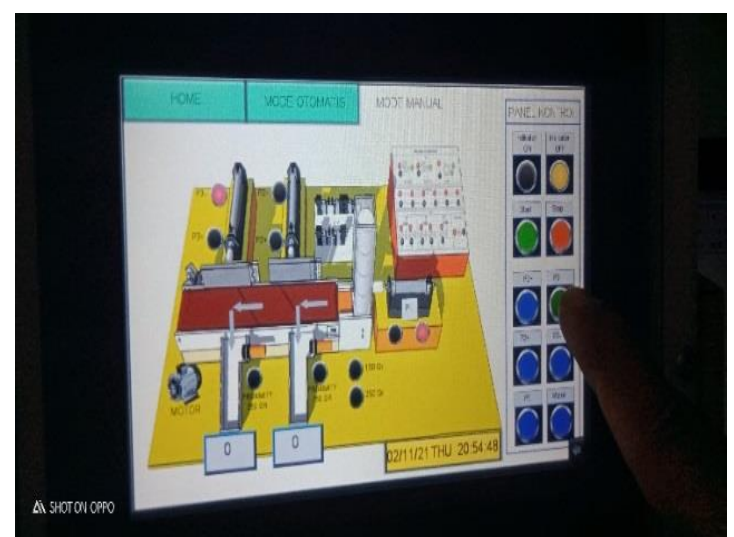

Gambar 12. kondisi tombol virtual Pneumatik 3 ditekan

Gambar 12 memperlihatkan kondisi ketika tombol Virtual pada HMI P3- untuk Pneumatik 3kembali pada keadaan semula. 


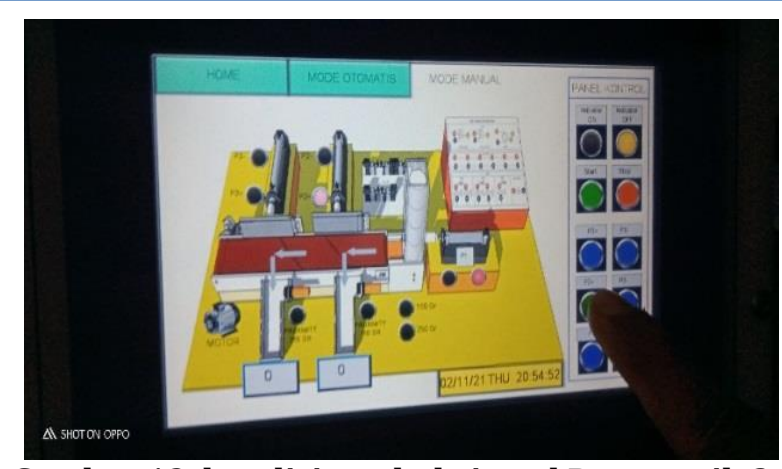

Gambar 13. kondisi tombol virtual Pneumatik 2+ ditekan

Gambar 13 memperlihatkan kondisi ketika tombol Virtual pada HMI P2+ untuk Pneumatik 2 mendorong kedepan mengarahkan benda dijalur sortir 150 gram.

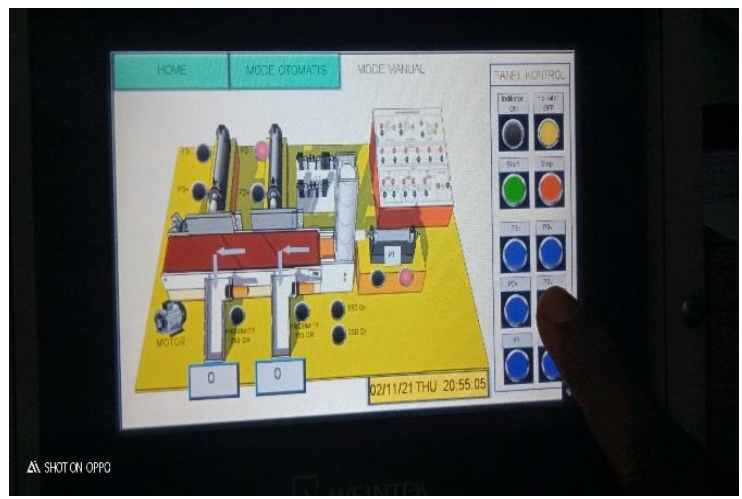

Gambar 14. kondisi tombol virtual Pneumatik 2ditekan

Gambar 14 memperlihatkan kondisi ketika tombol Virtual pada HMI P2- untuk Pneumatik 2 kembali pada keadaan semula.

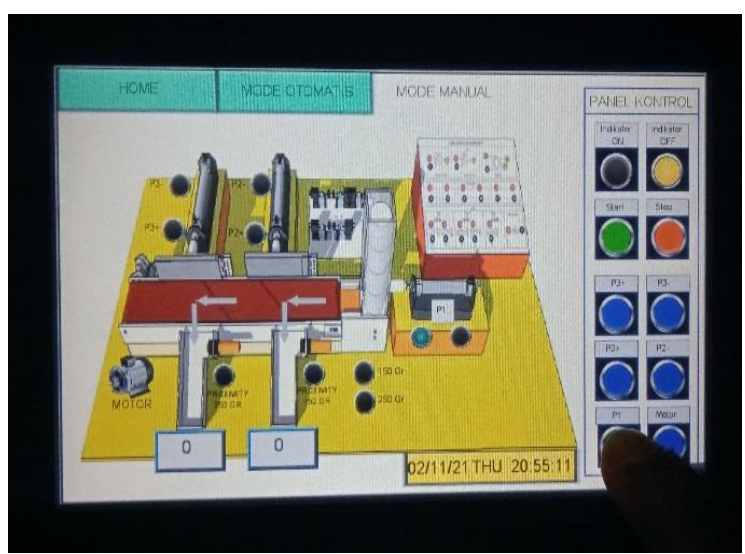

Gambar 15. kondisi tombol virtual Pneumatik p1 ditekan

Gambar 15 memperlihatkan kondisi ketika tombol Virtual pada HMI P1 untuk Pneumatik 1 mendorong kedepan mengarahkan benda ke tempat penmbangan benda. Selanjutnya pada 3 detik kemudian Pneumatk 1 akan kembali aktif untuk mendorong benda ke jalur konveyor yang akan menyortir benda.

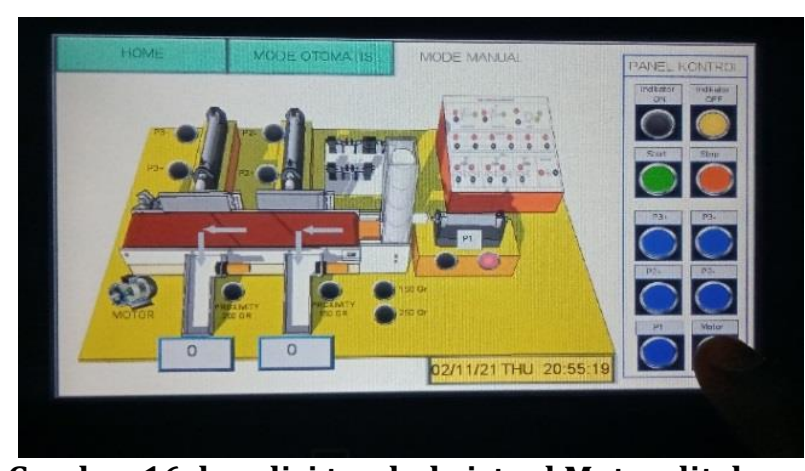

Gambar 16. kondisi tombol virtual Motor ditekan

Gambar 16 memperlihatkan kondisi ketika tombol Virtual motor pada HMI ditekan.

\section{Data Pengujian}

Pengujian sistem ditunjukkan pada Tabel 1 pengujian sistem merupakan pengujian keseluruhan kerja dari alat. Program PLC merupakan otak dari kerja alat. Pada tabel 1 dapat dilihat kondisi input output ketika sistem sedang bekerja. Angka 1 menunjukkan kondisi komponen dalam keadaan aktif dan angka 0 merupakan kondisi komponen dalam keadaan tidak aktif. Percobaan dilakukan sebanyak 10 kali percobaan.

Dari 10 data yang diambil tingkat keberhasilan benda masuk ke tempat pemilah :

$$
\frac{8}{10} \times 100 \%=80 \%
$$

\section{Tabel 1 Data pengujian alat}

\begin{tabular}{|c|c|c|c|c|c|c|c|c|c|c|c|}
\hline Percobaan & Benda & $\begin{array}{l}\text { LC } \\
150 \\
\text { gram }\end{array}$ & $\begin{array}{l}\text { LC } \\
\text { Gra } \\
\text { m }\end{array}$ & P1 & P2 & P2- & P3 \\
+ & P3- & $\begin{array}{c}\text { Proximity } \\
150 \text { gram }\end{array}$ & $\begin{array}{l}\text { Proximity } \\
250 \text { gram }\end{array}$ & $\begin{array}{l}\text { Benda } \\
\text { masuk } \\
\text { ketempat } \\
\text { pemilah }\end{array}$ \\
\hline 1 & $\begin{array}{l}150 \\
\text { gram }\end{array}$ & 1 & 0 & 1 & 1 & 0 & 0 & 1 & 1 & 0 & YA \\
\hline 2 & $\begin{array}{l}150 \\
\text { gram }\end{array}$ & 1 & 0 & 1 & 1 & 0 & 0 & 1 & 1 & 0 & YA \\
\hline 3 & $\begin{array}{l}250 \\
\text { gram }\end{array}$ & 0 & 1 & 1 & 0 & 1 & 1 & 0 & 0 & 1 & YA \\
\hline 4 & $\begin{array}{l}250 \\
\text { gram }\end{array}$ & 0 & 1 & 1 & 0 & 1 & 1 & 0 & 0 & 1 & YA \\
\hline 5 & $\begin{array}{l}150 \\
\text { gram }\end{array}$ & 1 & 0 & 1 & 1 & 0 & 0 & 1 & 1 & 0 & TIDAK \\
\hline 6 & $\begin{array}{l}250 \\
\text { gram }\end{array}$ & 0 & 1 & 1 & 1 & 0 & 0 & 1 & 0 & 1 & YA \\
\hline 7 & $\begin{array}{l}150 \\
\text { gram }\end{array}$ & 1 & 0 & 1 & 0 & 1 & 1 & 0 & 1 & 0 & TIDAK \\
\hline 8 & $\begin{array}{l}250 \\
\text { gram }\end{array}$ & 0 & 1 & 1 & 1 & 0 & 0 & 1 & 0 & 1 & YA \\
\hline 9 & $\begin{array}{l}150 \\
\text { gram }\end{array}$ & 1 & 0 & 1 & 1 & 0 & 0 & 11 & 1 & 0 & YA \\
\hline 10 & $\begin{array}{l}250 \\
\text { gram }\end{array}$ & 0 & 1 & 1 & 0 & 1 & 1 & 0 & 0 & 1 & YA \\
\hline
\end{tabular}

\section{PENUTUP}

Dari hasil pemograman sistem kontrol HMI untuk alat sortir benda menggunakan HMI WEINTEK MT8071iP ini dapat disimpulkan beberapa hal berikut.

1. Perancangan sitem kontrol HMI untuk alat sortir benda menggunakan HMI WEINTEK MT8071iP berjalan sesuai dengan fungsinya sebagai media kontrol dan monitoring sistem. Media kontrol, HMI WENTEK MT8071iP digunakan untuk 
mengoperasikan sistem kontrol melalui virtual button yang terdapat pada layar HMI WEINTEK MT8071iP pada mode pengoperasian otomatis dan manual. Media monitoring, operator dapat mengetahui kondisi alat dengan melihat visualisasi indikator-indikator berupa pushbutton virtual dan lampu indikator virtual yang muncul pada layar HMI WEINTEK MT8071iP.

2. Pemograman pada PLC bekerja sesuai dengan keinginan pada sistem kontrol alat sortir benda pada HMI WEINTEK MT8071iP. Hal ini dapat dilihat ketika operator menjalankan mode otomatis dan mode manual.

3. Pada hasil pengujian alat dapat dilihat bahwa untuk kedua sistem dapat bekerja dengan maksimal sehingga semua perintah yang dimasukkan diproses sesuai keinginan.

4. Dengan dibuatnya program untuk alat ini, kita bisa menguasai pemograman HMI WEINTEK MT8071iP menggunakan Software EasyBulder Pro yang digabungkan dengan PLC Omron dengan menggunakan CX-Programmer dan memahami bagaimana cara mengoperasikannya.

\section{REFERENSI}

[1] Midian, Jason. "Perancangan Sistem Antarmuka Berbasis HMI untuk Aplikasi Mesin Etching PCB", Skripsi, Universitas Indonesia, Jakarta, 2009.

[2] amin, A. "Human Machine Interface for Automation System of Handling Station. Human". MOTIVECTION: Journal of Mechanical, Electrical and Industrial Engineering, 1(3), 13-20. 2019.

[3] Haryanto, Heri. "Perancangan HMI Untuk Pengendalian Motor DC", Skripsi, Universitas Sultan Ageng Tirtayasa, Banten, 2012.

[4] Nurpulaela, Lela, "Perancangan Human Machine Interface Dengan Vb6.0 Untuk Visualisasi Dan Monitoring Kecepatan Motor Ac 3phase Pada Plc Omron Cj1m". Jurnal Teknosain, Volume IX, Nomor 1. 2012.

[5] Putra Dasril, Aldo. "Perancangan Human Machine Interface untuk Sistem Otomasi Storage Berbasis PLC". JTEV-Volume V, No 1. ISSN:2303-3309. 2019.

[6] Kadang, Stenly. "Aplikasi SCADA Pada Proses pasteursasi Pengisian dan Pengepakan Produk Susu Kemasan Pada Mini DCS Berbasis PLC Omron CPM2A", Skripsi, Universitas Sanata Dharma, Yogyakarta, 2009.

[7] Firman, "Pengembangan Trainer Elektropneumatik pada Mata Kuliah Pratikum Sistem Pengaturan PLC dan Pneumatik di Jurusan Teknik Elektro Fakultas Teknik Universitas Negeri Padang", Universitas Negeri Padang, Padang, 2018.

\section{Biodata Penulis}

Doli Hasbi Simanjuntak, dilahirkan di Padang, 08 juli 1995. Menyelesaikan D IV Teknik Elektro Industri pada Jurusan Teknik Elektro Fakultas Teknik Universitas Negeri Padang.

Risfendra, S.Pd, M.T, Ph.D, lahir di Riau, 13 Februari 1979. Sarjana Teknik Elektronika di Universitas Negeri Padang, lulus tahun 2004, S2 Teknik Sistem Pengaturan, ITS tahun 2008. S3 Shouten Taiwan University of science and technology, Taiwan tahun 2017. Staf pengajar pada Jurusan Teknik Elektro FT UNP sejak tahun 2005 sekarang. 